\title{
Profesinės intersticinės plaučių ligos
}

\author{
Kristina Stravinskaitè \\ LSMU MA Pulmonologijos ir imunologijos klinika
}

Reikšminiai žodžiai: profesinès plaučių ligos, intersticinès plaučių ligos, pneumokoniozès.

Santrauka. Straipsnyje nagrinėjami profesinių intersticinių plaučių ligų diagnostikos ir gydymo aspektai.

Pramonè vystosi, keičiasi ir darosi vis sudètingesnè. Tikètina, kad toksiniu medžiagu kiekis ore tik didès, o plaučiu reakcija ị ịkvejpiamąsias medžiagas vargu ar reikšmingai keisis. Taigi ateityje greičiausiai susidursime su jau žinomomis plaučių ligomis, bet su naujomis jų priežastimis.

Profesines intersticines plaučiu ligas (IPL) sukelia ¡kvepiamieji profesiniai veiksniai. Klinikinè, radiologinè ir patologine šių ligu išraiška panaši ị neprofesinių IPL. Todèl tiriant kiekvieną IPL sergantį pacientą svarbu surinkti išsamią profesinę anamnezę. Kenksmingų ịkvepiamụjų medžiagų ekspozicija IPL gali sukelti tiesiogiai ir didina idiopatinès plaučių fibrozès riziką. Profesinès IPL sudaro nuo 4 iki 18 proc. visu IPL (1, 2 lentelès).

Itarti, kad IPL yra profesiné, reikia tada, kai pacientas jaunesnio amžiaus, ta pačia liga serga kartu dirbantys asmenys, ligos simptomai pablogèja darbe, liga progresuoja lètai.
1 lentelè. Profesiniai veiksniai, galintys sukelti intersticines plaučiu ligas

\begin{tabular}{l}
\hline $\begin{array}{l}\text { Ikvepiamosios neorganinès } \\
\text { dulkès }\end{array}$ \\
\hline Silikatai \\
\hline Silicis, asbestas, talkas \\
\hline $\begin{array}{l}\text { Baltmolis, aliuminio silikatas } \\
\text { su Fe ir Mg }\end{array}$ \\
\hline Nefelinas, aliuminio silikatas \\
\hline Portlando cementas \\
\hline K ir Mg, aliuminio silikatas \\
\hline Berilis \\
\hline Anglis \\
\hline Anglies dulkės, grafitas \\
\hline $\begin{array}{l}\text { Ikvepiamosios organinès } \\
\text { dulkès }\end{array}$ \\
\hline $\begin{array}{l}\text { Termofiliniai grybai, tikrieji } \\
\text { grybai }\end{array}$ \\
\hline Bakterijos, gyvūnų baltymai \\
\hline
\end{tabular}

\begin{tabular}{l}
\hline Metalai \\
\hline Alavas, aliuminis \\
\hline $\begin{array}{l}\text { Kadmis, titanas, niobis, kobaltas, } \\
\text { hafnis, vanadis }\end{array}$ \\
\hline Geležis, antimonis, hematitas \\
\hline Sidabro ir geležies oksido dulkės \\
\hline Kitos ịkvejpiamosios dulkès \\
\hline $\begin{array}{l}\text { Chemikalai (orlonas, poliesteris, } \\
\text { neilonas, akrilas, vinilo chloridas) }\end{array}$ \\
\hline $\begin{array}{l}\text { Dujos (deguonis, NO, SO, chloro } \\
\text { dujos) }\end{array}$ \\
\hline $\begin{array}{l}\text { Dūmai (cinko, kario, kadmio, } \\
\text { geležies, mangano, nikelio, alavo } \\
\text { oksidas) }\end{array}$ \\
\hline $\begin{array}{l}\text { Garai (hidrokarbonatai, } \\
\text { gyvsidabris) }\end{array}$ \\
\hline $\begin{array}{l}\text { Aerozoliai (nafta, alyva, tepalai, } \\
\text { piretrumas) }\end{array}$
\end{tabular}

2 lentelè. Intersticinès plaučiu ligos, kurias gali sukelti profesiniai veiksniai

\begin{tabular}{|c|c|c|}
\hline Klinikinè išraiška & Patologinè išraiška & Profesinė priežastis \\
\hline Idiopatinė plaučių fibrozė & Iprastinė intersticinè pneumonija & Asbestas, plutonis, urano kasyba \\
\hline Nespecifinè intersticinė pneumonija & Nespecifinė intersticinė pneumonija & Organiniai antigenai \\
\hline Deskvamacinė intersticinè pneumonija & Deskvamacinè intersticinè pneumonija & Tekstilè, aliuminio suvirinimas, neorganinės dalelès \\
\hline $\begin{array}{l}\text { Obliteracinis bronchiolitas ir besiorgani- } \\
\text { zuojanti pneumonija }\end{array}$ & $\begin{array}{l}\text { Obliteracinis bronchiolitas ir besiorgani- } \\
\text { zuojanti pneumonija }\end{array}$ & Aerozoliu dažoma tekstilè akraminas, azoto oksidas \\
\hline Alveolių proteinozė & Alveolių proteinozė & Didelių dozių ekspozicija siliciu, aliuminio dulkės \\
\hline SRDS/ūminè intersticiné pneumonija & Difuzinis alveolių pažeidimas & $\begin{array}{l}\text { Dirginantis ikvepiamasis pažeidimas - NO, SO, } \\
\text { kadmio, berilio, chlorido, rūgščių mišinys }\end{array}$ \\
\hline Obliteracinis bronchiolitas & Konstrikcinis bronchiolitas & NO, chlorido dujos \\
\hline Bronchiolitas & Ląstelinis bronchiolitas & Organiniai antigenai \\
\hline Sarkoidozė & Granuliominis uždegimas & Berilis, organiniai antigenai, cirkonis aliuminis, titanas \\
\hline Lipoidinė pneumonija & Lipoidinè pneumonija & Metalurgija \\
\hline
\end{tabular}




\section{PROFESINIŲ IPL DIAGNOSTIKOS PRINCIPAI}

Profesinė IPL nustatoma esant šiems diagnostiniams kriterijams:

- Ekspozicija žinomu profesiniu veiksniu, galinčiu sukelti IPL, bei atitinkamas latentinis periodas.

- Būdingi klinikiniai, fiziniai ir radiologiniai požymiai.

- Kitos priežasties, galinčios sukelti IPL, nebuvimas.

Plaučių audinio biopsija, jei yra šie trys kriterijai, nebūtina. Plaučių audinio biopsija atliekama, kai ligos eiga netipinè, ar veikẻ naujas ar mažai žinomas profesinis veiksnys.

\section{PROFESINIŲ IPL GYDYMO PRINCIPAI}

Profesinių IPL gydymas mažai skiriasi nuo neprofesinių IPL gydymo. Pagrindinè ligos progresavimo lètinimo sąlyga - kontakto su IPL sukèlusiu profesiniu veiksniu nutraukimas. Labai svarbu mesti rūkyti. Kiekvienas naujas profesinès IPL atvejis yra ispejjimas, kad ir kiti kartu dirbantys asmenys gali sirgti ta pačia liga.

Didžiosios dalies profesinių IPL veiksmingo, įrodymais pagrịsto gydymo nèra. Tačiau pacientui galima pagelbèti skiriant adekvatų simptominị gydymą: taikyti deguonies terapiją, laiku pradèti gydyti kvejpavimo taku infekcijas, lètinę plautinę širdị.

\section{PNEUMOKONIOZE்}

Pneumokoniozè - tai IPL, kurią sukelia ilgalaikè oro, kuriame yra didelè neorganinių dulkių koncentracija, ekspozicija.

Pneumokoniozę lemia darbo kenksmingomis sąlygomis trukmè, ekspozicijos intensyvumas, medžiagu dalelių rūšis, savybès, apsaugos priemonių naudojimas.

Geriausiai ištirtos yra silicio, asbesto, berilio, anglies sukeltos pneumokoniozès.

\section{SILIKOZE்}

Silikozė yra fibronodulinė plaučių liga, kurią sukelia silicio kristalų (alfa kvarco, kristobalito ir tridimito) turinčių dulkių ịkvejpimas ir kaupimasis plaučiuose. Kvarcas yra dažniausia silicio kristalo forma, kurio gausu granite (30 proc. laisvo $\mathrm{Si}$ ), šiferyje (40 proc. $\mathrm{Si}$ ), smiltainyje (grynas $\mathrm{Si}$ ).

Silicio sukeltos plaučių ligos aprašomos jau nuo antikos laikų Egipte ir Graikijoje. JAV 1987-1996 nustatyta nuo 3600 iki 7300 silikozès atvejų per metus. Per ši laikotarpi registruota apie 3 tūkst. mirties nuo silikozès atvejų. Per pastaruosius 30 metų mirčių nuo silikozès labai sumažèjo dèl geresnès darbuotojų apsaugos.

Silicio kristalai paplitę natūralioje gamtoje nesuardytos formos: uolos, žemès pluta, geležies rūda. Silikoze rizikuoja susirgti žmonès, kurių darbas susijęs su šių medžiagų ardymu, rinkimu ar valymu (anglies rūdos, tunelių kasyba, akmenų skaldymas, darbas karjere, gręžimas, darbas liejykloje, mūrijimas, aukštakrosnès, plieno dirbiniu gamyba, valcavimo staklynas, cemento ir betono, stiklo gamyba, valymas sméliasroviu, statybos).

Skiriamos kelios silikozès klinikinès formos. Lètinè silikozè išsivysto praejjus 10-30 metu po buvusio kontakto su siliciu. Tik mažai daliai asmenų pasireiškia progresuojanti masyvi fibrozè.

Greitesnès eigos silikozè išsivysto praejjus iki 10 metu po buvusio kontakto su siliciu. Susijusi su didele silicio ekspozicija. Sergant greitesnès eigos silikoze yra didelè rizika, kad išsivystis progresuojanti masyvi fibrozè.

Progresuojanti masyvi fibroze. Klinikiniai simptomai būna labai ryškūs. Progresuoja kvẻpavimo funkcijos nepakankamumas (KFN), emfizema, lètinè plautinè širdis.

Ūminè silikozé susijusi su didelès koncentracijos silicio kristalo dulkių ikvėpimu. Simptomai atsiranda po kelių savaičių ar keleto metų po kontakto. Būdinga staigi simptomų pradžia. Dažniausi simptomai yra kosulys, svorio mažejimas, nuovargis, pleuros skausmas, traškantys karkalai. Ūminès silikozès prognozė bloga, greitai vystosi kvejpavimo funkcijos nepakankamumas, plautinè širdis. Gyvenimo trukmè nuo simptomų pradžios - apie 4 metai. Dažnai komplikuojasi tuberkulioze (TBC) ar grybeline liga.

Silikozė glaudžiai susijusi su plaučių vèžiu. 1997 m. tarptautinè plaučių véžio tyrimų agentūra patvirtino silicio oksidą kaip kancerogeną.

Nustatytas stiprus ryšys tarp silikozès ir tuberkuliozès bei ne tuberkuliozès mikobakterinès infekcijos. Sergant silikoze, yra didelè rizika susirgti ūmine TBC, todèl pacientai turi būti tiriami dèl latentinès infekcijos. Silikozè siejama ir su sklerodermija, reumatoidiniu artritu, sistemine raudonąja vilklige, sisteminiu vaskulitu. Sergantieji silikoze dažnai serga kvėpavimo takų obstrukcija ir lètiniu bronchitu.

\section{Silikozès radiologinè diagnostika}

Skiriami trys silikozès radiologinių pokyčių variantai: paprastoji silikozè, progresuojanti masyvi fibrozè (PMF), silikoproteinozè.

Paprastajai silikozei būdingi dauginiai smulkūs $(<10 \mathrm{~mm})$ židiniai. Židiniai apskriti, bet gali būti ir nelygiais kraštais, išsidèstę išskirtinai viršutinèse skiltyse.

Progresuojanti masyvi fibrozė (ar konglomeratinè silikozè) vystosi tada, kai maži židiniai didejja ir susijungia ì didelius viršutinès bei vidurinès skilčių židinius, dèl viršutinès skilties fibrozès šaknys yra traukiamos i viršų. Būdinga šaknų adenopatija ir kalcifikacija.

Silikoproteinozė yra ūminès silikozès skiriamasis požymis. Būdinga apatinių dalių alveolių prisipildymo požymiai, nèra židinių ir limfmazgių kalkèjimo. Vẻlesnèmis stadijomis šie pokyčiai išplinta i vidurinę ir viršutinę skiltis. 


\section{Silikozès diagnostikos kriterijai}

Silikozès diagnozè nustatoma, kai yra šie trys požymiai: 1) anamnezėje kontaktas su siliciu, pakankama ekspozicija, kad sukeltu ligą, bei tam tikras latentinis periodas po pirmo kontakto, 2) krūtinès ląstos rentgenogramoje ar kompiuterinejje tomogramoje (KT) silikozei būdingi požymiai, 3) nėra požymių kitos ligos, galejjusios sukelti panašius pokyčius.

\section{Silikozès patologinè diagnostika}

Plaučių audinio biopsija atliekama, kai diagnozès negalima nustatyti kliniškai ar biopsijos reikia paneigti kitai diagnozei. Atliekama transbronchine biopsija ir bronchų bei alveolių nuoplovų tyrimas (BAL) ar atvira plaučių audinio biopsija.

Pagrindinis silikozès patologinis požymis - silikoziniai mazgai, kurių centre yra silicio dalelès, apsuptos kolageno, o periferijoje - makrofagai, limfocitai, fibroblastai. Silicio kristalai mazgo centre gali būti matomi poliarizuotos šviesos mikroskopu. Gali būti naudojamas ir elektroninis skenuojantis mikroskopas su rentgenospektroskopu.

\section{Silikozès gydymas}

Irodymais pagrịsto specifinio silikozès gydymo nėra. Svarbiausia - nutraukti tolesni kontaktą su silicio dulkėmis, mesti rūkyti. Rekomenduojami skiepai nuo gripo ir pneumokokinès infekcijos. Gliukokortikoidu gali būti skiriama ūminei silikozei gydyti. Lètinès silikozès gydymas jais nebuvo naudingas, nors vienoje studijoje pastebèta, kad kvèpavimo funkcija pagerejjo. Galutinèmis ligos stadijomis gali būti taikoma plaučių transplantacija. Kiti silikozès gydymo metodai yra tik eksperimentiniai: visų plaučių lavažas, aliuminio inhaliacijos, polivinilpiridino $\mathrm{N}$ oksido skyrimas paranteraliai. Kaip ir kitų IPL atveju, taikomas simptominis kvėpavimo takų obstrukcijos, plautinès širdies, KFN gydymas.

\section{ASBESTOŻ்}

$\mathrm{Su}$ asbestoze susijusios pramonès šakos yra statyba, laivų statyba, cemento gamyba, tekstilè, daržininkystè. Darbininkai, galintys susirgti asbestoze yra santechnikai, šaltkalviai, elektrikai, izoliacijos montuotojai, dailidès garo katilų gamintojai, suvirintojai, frezuotojai.

Asbestoze sergantys pacientai gali skųstis dusuliu fizinio krūvio metu, kosuliu, skrepliavimu, švokštimu krūtinèje. Auskultuojant girdèti abipus traškantys karkalai, yra plautinès širdies požymių. Būdinga, kad kvėpavimo funkcijos tyrimais nustatoma VC, TLC sumažèjimas, DLCO sumažèjimas, nebūdinga kvėpavimo takų obstrukcija.

\section{Asbestozès radiologinè diagnostika}

Asbestoze sergančių ligonių plaučių rentgenogramoje matyti maži patamsejjimai abipus parenchimos, turintys daugiažidininị ar retikulinị pobūdị. Dažni pleuros po- kyčiai - pleuros plokštelès. Nebūdinga limfadenopatija. Paprastai, sergant asbestoze, pirmiausia pažeidžiamos apatinès plaučiu dalys, kartu yra ir abipusių pleuros pokyčių. Pleuros apnašos - patognominis požymis, rodantis buvus kontaktą su asbestu.

Krūtinès ląstos KT matyti ịvairaus intensyvumo linijinių popleurinių sutankẻjimų, einančių lygiagrečiai su pleura, plaučiu pamatinių nugarinių dalių parenchimos fibrozè su peribronchine, intralobuline in interlobarine pertvarų fibroze. Kai liga pažengusi, matyti grubus korètumas, grubios parenchimos drožès, dažnai susiliejančios su pleura, pleuros plokštelès.

\section{Asbestozès patologinè diagnostika}

Asbestozès diagnozė nustatoma, kai plaučių audinio biopsijoje randama asbesto pluoštų (asbesto kūnelių) kartu su intersticine plaučiu fibroze. Asbesto kūneliai tai asbesto pluoštai, kuriuos dengia geležis ir baltymas. Jų gali būti ir bronchų bei alveolių nuoplovose, indukuotuose skrepliuose.

Asbestozès diagnostiniai kriterijai yra šie: 1) anamnezejje buvęs kontaktas su asbestu ir tam tikras latentinis periodas nuo kontakto pradžios iki ligos pasireiškimo ir/ar kontakto su asbestu žymenų nustatymas (pleuros plokštelès ar tam tikro kiekio asbesto kūnelių radimas bronchų bei alveolių nuoplovose ar plaučių audinyje), 2) aiškūs intersticinès fibrozès požymiai (vienas ar keli: traškantys karkalai, sumažèję VC ir/ar DLCO, tipiniai pokyčiai plaučiu rengenogramoje ar kompiuterinejje tomogramoje, histologiniai plaučiu fibrozès požymiai), 3) nèra kitų difuzinès IPL priežasčių.

\section{Asbestozès gydymas}

Specifinio asbestozès gydymo nèra. Šiu pacientų stebejjimas pagrịstas ligos progresavimo stabdymu, t. y. pacientai turi mesti rūkyti, ateityje vengti kontakto su asbestu. Pacientams skiriama nuolatinè deguonies terapija esant KFN, gydoma kvėpavimo takų infekcija, skiepijama nuo gripo, pneumokoko.

\section{LĖTINĖ BERILIO LIGA (BERILIOZE்)}

Pirmą kartą lètinė berilio liga (LBL) aprašyta 1946 m. JAV, kai 17 darbuotojų, kurie dirbo su fluorascentinèmis lempomis, nustatyta dauginių granuliomuc plaučiuose.

LBL - granuliominè liga, panaši ị sarkoidozę. Apie 6 proc. pacientų, kuriems diagnozuota sarkoidozè, iš tikrųjų serga LBL.

Pramonès šakos, kuriose naudojamas berilis yra šios: metalo ir metalo lydinių (berilis/varis) mašinu imonès, elektronika, gynybos pramonè, berilio gavyba, automobiliu, keramikos, kompiuterių, kosmonautikos, metalo utilizacijos pramoné, elektronikos ir kompiuterių perdirbimas, juvelyrinių dirbinių gamyba, dantų protezu gamyba. LBL dažnumas visų berilị naudojančioje pramonẻje dirbusių asmenų grupéje yra $1-5$ proc. 


\section{LBL patogenezè}

Latentinis LBL periodas - nuo 2 mén. iki 40 metų. Berilis sukelia imuninę reakciją kontaktą su juo turejjusiems ir icijautrinusiems asmenims: in vitro periferinio kraujo limfocitu proliferacinis atsakas (būdingas tik beriliui), plaučiuose padideja CD4+ T ląstelių, formuojasi granuliomos. Beriliozè yra su HLA susijusi liga. Nenormalų imuninị atsaką lemia vienos aminorūgšties pokytis HLA molekuleje. HLA-DP $\beta 1$ variantas nustatomas 85 proc. LBL sergančiu asmenų.

Beriliozès klinikiniai simptomai nespecifiniai. Tai sausas kosulys, dusulys, naktinis prakaitavimas, nuovargis, svorio mažejimas, astmai būdingi simptomai, odos mazgeliai. Gali būti pažeisti ir kiti organai (oda, kepenys, blužnis, miokardas, skeleto raumenys ir kt.). Auskultuojant girdèti drègni karkalai, pastebima plautinès širdies simptomų. Kraujo tyrimuose gali būti hiperkalciemija, hiperkalciurija. Sumažejja dujų difuzija, spirogramoje: obstrukcija, restrikcija ar mišrus kvėpavimo funkcijos sutrikimas.

Berilio limfocitu proliferacijos tyrimas (BeLPT) tai standartinis tyrimo metodas klinikinèje praktikoje nustatyti kontaktą su beriliu turẻjusių asmenų issijautrinimą beriliui, sarkoidozès diferencinei diagnostikai. Kraujo ar bronchų bei alveolių nuoplovu mononuklearinès ląstelès in vitro yra veikiamos įvairios koncentracijos berilio druska ịvairiais laiko intervalais. Nustatomas T limfocitu gebejjimas atpažinti berilị kaip Ag ir ju proliferacija. Tokios limfocitų reakcijos nesukelia kiti metalai, ji nebūdinga ir kontaktą su beriliu turèjusiems asmenims, kuriems nèra LBL požymių.

\section{$L B L$ radiologinè diagnostika}

Sergančio LBL ligonio plaučių rentgenogramoje būdinga tarpuplaučio limfadenopatija, retikulionoduliniai pokyčiai. Krūtinès ląstos KT: parenchimos mazgai, matinio stiklo vaizdas, tarpuplaučio, šaknų limfadenopatija, sustorèjusi pleura. Konglomeratų masès ir emfizema išryškejja vẻlyvose stadijose. 25 proc. atvejų nebūna jokių radiologinių pokyčių.

\section{LBL patologinè diagnostika}

LBL transbronchinès biopsijos medžiagoje būdinga nekazeozinès granuliomos ir/ar mononuklearinių ląstelių intersticinių ląstelių infiltratai. Mineralų analitiniu metodu galima išmatuoti berilio koncentraciją granuliomose.

LBL diagnozès kriterijai: 1) anamnezèje darbas su beriliu, teigiamas kraujo ar bronchų bei alveolių nuo- plovų BeLPT bei plaučių biopsinėje medžiagoje - nekazeozinès plaučių granuliomos ir/ar mononuklearinių ląstelių intersticinių ląstelių infiltratai.

\section{LBL gydymas}

Svarbiausia - nutraukti kontaktą su beriliu. Kai beriliozè yra ankstyvų stadijų, pacientai gali būti stebimi neskiriant jokio gydymo. Nèra klinikinių studijų, kuriomis būtų įvertintas gliukokortikoidų (GK) poveikis LBL, tačiau jau apie 30 metu aprašoma, kad LBL gydant GK efektas itin veiksmingas. GK pradedama gydyti, kai gyvybinè talpa bei dujų difuzija sumažèja 10 proc. nuo pradinio ar jau sutikusi kvejpavimo funkcija. Jei vartoti GK pacientas negali, skiriama imunosupresinių vaistų (pvz., metotreksato)

\section{NAUJOS INTERSTICINĖS PROFESINĖS PLAUČIŲ LIGOS}

Neilono sukeltas plaučių pažeidimas (angl. Nylon flock workers lung) sąlygoja limfocitini bronchiolitą ir peribronchiolitą. Krūtinès ląstos KT būdingas matinio stiklo vaizdas, trakcinès bronchektazès.

Ardistilio sindromą (angl. Textile sprayers lung) sukelia tekstilejje naudojama medžiaga akraminas. Radiologinis tyrimas - abipusė infiltracija, konsolidacija. Biopsija - besiorganizuojanti pneumonija. Būdinga greitai progresuojanti eiga.

\section{APIBENDRINIMAS}

Vystantis pramonei, daugejja įkvepiamųjų toksinių medžiagų. Profesinių IPL klinikinè, radiologinè ir patologinè išraiška panaši i kitų IPL. Pagrindinis profesinių IPL gydymo principas - kontakto su žalingu profesiniu veiksniu nutraukimas, nes veiksmingo, irodymais pagrịsto gydymo nèra.

\section{OCCUPATIONAL INTERSTITIAL LUNG DISEASES}

\section{KRISTINA STRAVINSKAITÉ \\ DEPARTMENT OF PULMONOLOGY AND IMMUNOLOGY LITHUANIAN UNIVERSITY OF HEALTH SCIENCES}

Keywords: occupational lung diseases, interstitial lung diseases, pneumoconiosis.

Summary. The main diagnostic and treatment problems of Occupational Interstitial Lung Diseases are discussed in this article

\section{LITERATŪRA}

1. Valiante DJ; Schill DP; Rosenman KD; et.al. Highway repair: a new silicosis threat. Am J Public Health 2004;94(5):876-80.

2. Silicosis mortality, prevention, and control-United States, 1968-2002. MMWR Morb Mortal Wkly Rep 2005; 29;54(16):401-5.

3. Sichletidis L; Chloros D; Spyratos D; et al. Mortality from occupational exposure to relatively pure chrysotile: a 39-year study. Respiration. 2009;78(1):63-8

4. Maier LA Clinical approach to chronic beryllium disease and other nonpneumoconiotic interstitial lung diseases. J Thorac Imaging 2002;17(4):273-84

5. Newman LS; Mroz MM; Balkissoon R; et.al Beryllium sensitization progresses to chronic beryllium disease: a longitudinal study of disease risk. Am J Respir Crit Care Med 2005;171(1):54-60. 